\title{
Body Mass Index 25 or Greater
}

National Cancer Institute

\section{Source}

National Cancer Institute. Body Mass Index 25 or Greater. NCI Thesaurus. Code C158479.

Indicates a body mass index measurement of 25 or higher. 